\title{
Development of silicon carbide fiber-reinforced silicon carbide matrix composites with high performance based on interfacial and microstructure control
}

\author{
Katsumi YOSHIDA ${ }^{\dagger}$ \\ Research Laboratory for Nuclear Reactors, Tokyo Institute of Technology, 2-12-1, Ookayama, Meguro-ku, Tokyo $152-8550$
}

Continuous $\mathrm{SiC}$ fiber-reinforced $\mathrm{SiC}$ matrix composites $\left(\mathrm{SiC}_{\mathrm{f}} / \mathrm{SiC}\right)$ have been considered to be a key material as structural components for aerospace and energy fields. This paper reviews novel fabrication process of continuous $\mathrm{SiC}_{\mathrm{f}} / \mathrm{SiC}$ composites with high performance based on interfacial and microstructure control and our approach to improvement of mechanical and thermal properties of $\mathrm{SiC}_{\mathrm{f}} / \mathrm{SiC}$ composite based on modeling and analysis. The simple fabrication process of two-dimensional $\mathrm{SiC}_{\mathrm{f}} / \mathrm{SiC}$ composite using sheet stacking and hot-pressing based on interfacial and microstructure control was developed, and dense $\mathrm{SiC}_{\mathrm{f}} / \mathrm{SiC}$ composite with excellent mechanical and thermal properties was successfully obtained. Furthermore, novel fabrication process of $\mathrm{SiC}_{\mathrm{f}} / \mathrm{SiC}$ composite using EPD process was proposed and it was demonstrated that EPD process is expected to be an effective way to control the fiber/matrix interface and the microstructure of $\mathrm{SiC}_{\mathrm{f}} / \mathrm{SiC}$ composite with high performance. Interfacial properties of $\mathrm{SiC}_{\mathrm{f}} / \mathrm{SiC}$ composite were quantitatively evaluated by push-in test using nanoindenter, and these quantitative results well agreed with the results on their mechanical properties, and these results lead to the material design of the $\mathrm{SiC}_{\mathrm{f}} / \mathrm{SiC}$ composite with high mechanical properties and the optimization of its fabrication process. Simple model of thermal conductivity of $\mathrm{SiC}_{\mathrm{f}} / \mathrm{SiC}$ composite based on series model of multilayered structure was suggested by our experimental data, and higher thermal conductivity of $\mathrm{SiC}_{\mathrm{f}} / \mathrm{SiC}$ composite was successfully achieved by microstructure control.

(C2010 The Ceramic Society of Japan. All rights reserved.

Key-words : $\mathrm{SiC}_{\mathrm{f}} / \mathrm{SiC}$ composite, Interfacial and microstructure control, Mechanical properties, Thermal properties, Interfacial properties, Hot-pressing, Electrophoretic deposition

[Received November 2, 2009]

\section{Introduction}

Silicon carbide $(\mathrm{SiC})$ is one of the promising materials for structural applications at high temperatures because it shows high thermal and chemical stability, high stiffness, high hardness, high thermal conductivity, excellent oxidation, corrosion and wear resistance, high mechanical strength at high temperature, low thermal expansion, and good resistance to high-energy neutron irradiation. ${ }^{1-4)}$ However, monolithic $\mathrm{SiC}$ shows low reliability due to its brittleness and catastrophic fracture behavior, and the applications of monolithic $\mathrm{SiC}$ as high temperature structural parts have been limited. In order to improve its reliability, SiC matrix reinforced with continuous $\mathrm{SiC}$ fibers with high elastic modulus and strength, i.e. continuous $\mathrm{SiC}$ fiber-reinforced $\mathrm{SiC}$ matrix composites $\left(\mathrm{SiC}_{\mathrm{f}} / \mathrm{SiC}\right)$, which show pseudo-ductile fracture behavior and high fracture energy, have been paid attention as the ceramic materials with high reliability. Continuous $\mathrm{SiC}_{\mathrm{f}} /$ $\mathrm{SiC}$ composites are expected to be applied as components for high temperature gas turbine, spacecrafts and future fusion reactors, ${ }^{5-7)}$ and they have been considered as a key material for these applications. During fracture of fiber-reinforced ceramic matrix composite, complicated processes with interfacial debonding, fiber bridging, fiber fracture and fiber pullout occur. $^{8)-11)}$ As a result, energy for fracture in fiber-reinforced ceramic matrix composite increases significantly. It is important

Corresponding author: K. Yoshida; E-mail: k-yoshida@nr.titech. ac.jp for unique fracture behavior in fiber-reinforced ceramic matrix composite to design the optimum fiber/matrix interface and microstructure. The optimum interface plays an important role for the promotion of fiber pullout and interfacial debonding, and for the inhibition of reaction between fiber and the matrix. ${ }^{12), 13)}$ Currently, carbon or boron nitride (BN) coating is formed on $\mathrm{SiC}$ fibers by chemical vapor deposition (CVD) to obtain the optimum fiber/matrix interface in $\mathrm{SiC}_{\mathrm{f}} / \mathrm{SiC}$ composite. ${ }^{14), 15)}$

Continuous $\mathrm{SiC}_{\mathrm{f}} / \mathrm{SiC}$ composites are mainly fabricated by chemical vapor infiltration (CVI) method, polymer infiltration and pyrolysis (PIP) method and reaction sintering process. ${ }^{16)-19)}$ $\mathrm{CVI}$ and PIP processes have some advantages such as $\mathrm{SiC}$ matrix with high purity, minimizing damage to fibers, and making nearnet shape parts. On the other hand, these processes require longer manufacturing times and complicated apparatus, resulting in high cost. In addition, the $\mathrm{SiC}_{\mathrm{f}} / \mathrm{SiC}$ composites fabricated by these processes usually contain large amount of voids and pores, resulting in low mechanical and thermal properties. Reaction sintering process offers dense $\mathrm{SiC}$ matrix in $\mathrm{SiC}_{\mathrm{f}} / \mathrm{SiC}$ composite without shrinkage during sintering. However, molten silicon has high reactivity and it leads to damage of fibers and bonding between fiber and matrix. Moreover, free silicon in $\mathrm{SiC}$ matrix deteriorates the mechanical properties of $\mathrm{SiC}_{\mathrm{f}} / \mathrm{SiC}$ composite at high temperature because melting point of silicon is around $1410^{\circ} \mathrm{C}$. For the practical use of continuous $\mathrm{SiC}_{\mathrm{f}} / \mathrm{SiC}$ composites as structural parts, establishment of the fabrication process of continuous $\mathrm{SiC}_{\mathrm{f}} / \mathrm{SiC}$ composites with high performance that is simple compared with conventional methods and leads to dense 
composite has been strongly requested.

This paper reviews novel fabrication process of continuous $\mathrm{SiC}_{\mathrm{f}} / \mathrm{SiC}$ composites with high performance based on interfacial and microstructure control and our approach to improvement of mechanical and thermal properties of $\mathrm{SiC}_{\mathrm{f}} / \mathrm{SiC}$ composite based on modeling and analysis.

\section{Fabrication process of $\mathrm{SiC}_{\mathrm{f}} / \mathrm{SiC}$ composites based on interfacial and microstructure control}

\subsection{Fabrication of $\mathrm{SiC}_{\mathrm{f}} / \mathrm{SiC}$ composites using sheet stacking and hot-pressing}

Hot-pressing is a simple process compared with CVI, PIP and reaction sintering, and it offers the ability to fabricate dense $\mathrm{SiC}_{\mathrm{f}} /$ $\mathrm{SiC}$ composite. However, hot-pressing usually requires higher temperature for sintering than these processes, and it had been avoided for the fabrication of $\mathrm{SiC}_{\mathrm{f}} / \mathrm{SiC}$ composite due to the thermal degradation of fiber during sintering. Basically, sintering of $\mathrm{SiC}$ ceramics needs sintering additives due to the covalent nature of $\mathrm{Si}-\mathrm{C}$ bonding and low self-diffusion coefficient, ${ }^{20)}$ and sintering additives that enable low-temperature sintering must be selected for the fabrication of $\mathrm{SiC}_{\mathrm{f}} / \mathrm{SiC}$ composite in order to inhibit the thermal degradation of fiber. To satisfy this require- ment, $\mathrm{Al}_{2} \mathrm{O}_{3}-\mathrm{Y}_{2} \mathrm{O}_{3}-\mathrm{CaO}$ system that can promote the densification of $\mathrm{SiC}$ ceramics via liquid phase sintering at lower temperature by hot-pressing ${ }^{21)}$ was selected for the fabrication of $\mathrm{SiC}_{\mathrm{f}} / \mathrm{SiC}$ composite. In addition, present authors reported that the degradation of fiber strength was accelerated by the diffusion of sintering additives from the matrix, ${ }^{22)}$ and strong bonding between fiber and the matrix was formed, and then fiber pullout was inhibited. ${ }^{23)}$ In order to inhibit the degradation of fibers and the reaction between fiber and the matrix, optimum interfacial and microstructure design must be considered for the fabrication of $\mathrm{SiC}_{\mathrm{f}} / \mathrm{SiC}$ composite. Based on interfacial and microstructure control, present authors proposed the simple fabrication process of two-dimensional $\mathrm{SiC}_{\mathrm{f}} / \mathrm{SiC}$ composites with high performance by sheet stacking and hot-pressing. Schematic illustration of the fabrication process of $\mathrm{SiC}_{\mathrm{f}} / \mathrm{SiC}$ composites using sheet stacking and hot-pressing is shown in Fig. 1. ${ }^{24)} \mathrm{SiC}$ green sheet was prepared by laboratory-scale tape casting apparatus using the slurry containing submicron-sized $\beta$-SiC powder, sintering additives of $\alpha-\mathrm{Al}_{2} \mathrm{O}_{3}(14$ mass $\%), \mathrm{Y}_{2} \mathrm{O}_{3}$ (4 mass $\left.\%\right)$ and $\mathrm{CaO}(2$ mass $\%)$, and some organics. ${ }^{25}$ Two dimensionally plain-woven Hi-Nicalon (Nippon Carbon Co., Ltd.) fiber cloths with BN coating (thickness; $0.4 \mu \mathrm{m}$ ) were used as the reinforcement. Polycarbosilane

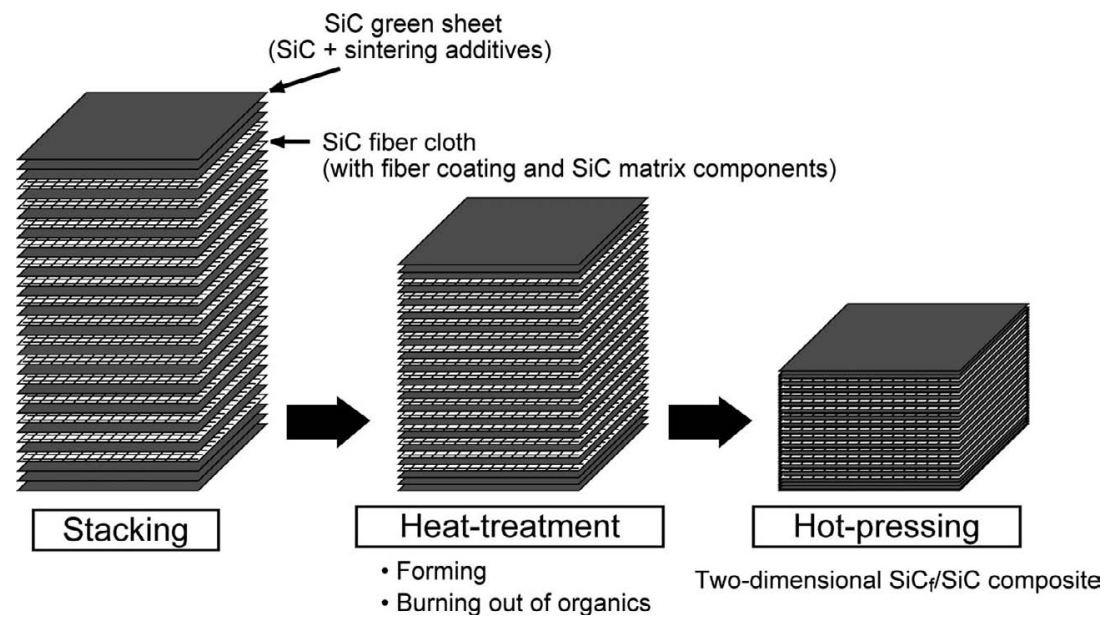

Fig. 1. Schematic illustration of the fabrication process of $\mathrm{SiC}_{\mathrm{f}} / \mathrm{SiC}$ composite using sheet stacking and hot-pressing.
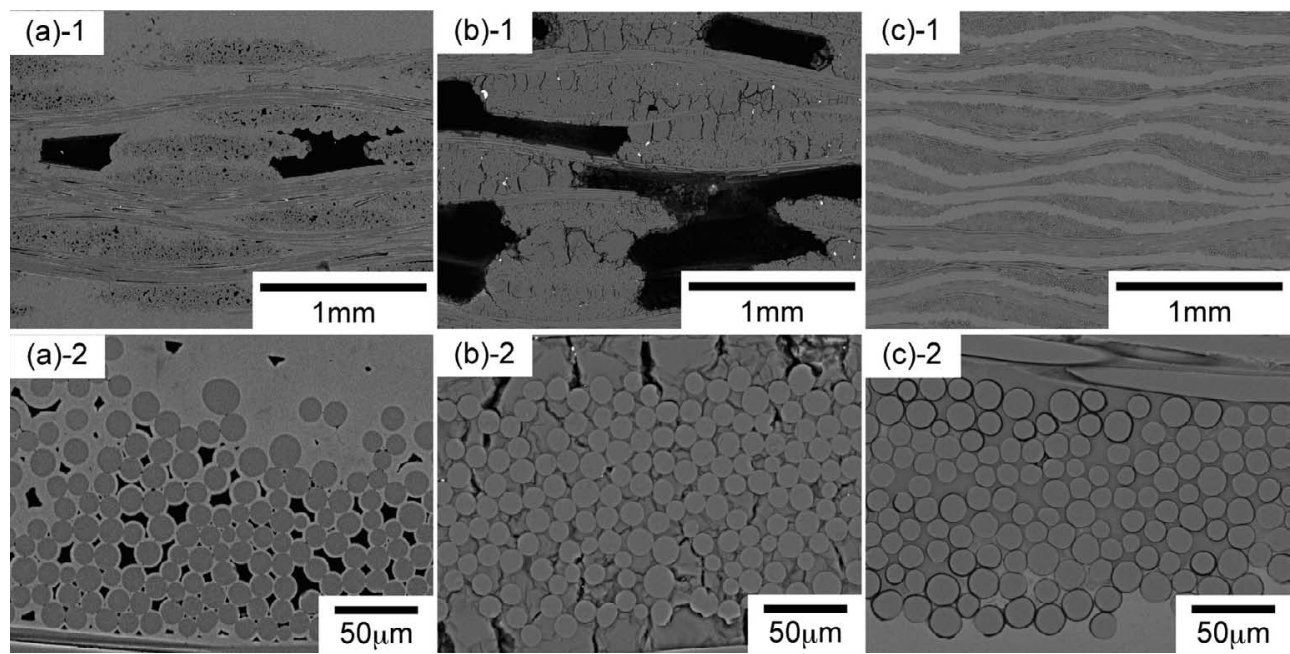

Fig. 2. SEM micrographs of the microstructure of $\mathrm{SiC}_{\mathrm{f}} / \mathrm{SiC}$ composites fabricated by (a) CVI process, (b) PIP process and (c) hot-pressing. (a)-(c)-1: Low magnification, (a)-(c)-2: High magnification. 
(PCS), precursor for $\mathrm{SiC},{ }^{26)-28)}$ was dissolved in toluene, and then impregnated into Hi-Nicalon fiber cloth. SiC green sheets and PCS-impregnated fiber cloths were stacked alternately, and then heat-treated at $300^{\circ} \mathrm{C}$ in air under a uniaxial pressure of $20 \mathrm{kPa}$. The stacked green compact was hot-pressed at $1650-1750^{\circ} \mathrm{C}$ for $1 \mathrm{~h}$ in argon flow under a uniaxial pressure of $40 \mathrm{MPa}$. Fiber volume fraction $\left(\mathrm{V}_{\mathrm{f}}\right)$ of the $\mathrm{SiC}_{\mathrm{f}} / \mathrm{SiC}$ composite was $52 \%$. It was expected that this fabrication process had the following advantages; $\mathrm{SiC}$ sheet between each fiber cloth layer would promote the densification of $\mathrm{SiC}_{\mathrm{f}} / \mathrm{SiC}$ composite, and the impregnation of PCS would contribute to the formation of SiC matrix between each fiber filament, protection of the diffusion of sintering additives into fibers and the promotion of fiber pullout by the inhibition of the reactions between fiber and the matrix.

Figure 2 shows the microstructure of $\mathrm{SiC}_{\mathrm{f}} / \mathrm{SiC}$ composites fabricated by CVI, PIP processes and hot-pressing. ${ }^{18), 24)}$ Large voids and pores were observed in the $\mathrm{SiC}_{\mathrm{f}} / \mathrm{SiC}$ composites fabricated by CVI and PIP processes. On the other hand, the $\mathrm{SiC}_{\mathrm{f}} /$ $\mathrm{SiC}$ composite fabricated by hot-pressing was dense (relative density: 93-94\%) and it did not contain voids and pores, and sufficient formation of $\mathrm{SiC}$ matrix between each fiber filaments was achieved.

Figures 3 and $\mathbf{4}$ exhibit typical load-displacement curves of $\mathrm{SiC}_{\mathrm{f}} / \mathrm{SiC}$ composites fabricated by hot-pressing at $1650^{\circ} \mathrm{C}-$ $1750^{\circ} \mathrm{C}$ in three-point bending test at room temperature and at high temperatures up to $1400^{\circ} \mathrm{C}^{24), 29)} \mathrm{SEM}$ micrograph of fracture surface of the $\mathrm{SiC}_{\mathrm{f}} / \mathrm{SiC}$ composite hot-pressed at $1700^{\circ} \mathrm{C}$ after bending test at room temperature are shown in Fig. 5. ${ }^{24)}$ The $\mathrm{SiC}_{\mathrm{f}} / \mathrm{SiC}$ composites fabricated by hot-pressing showed pseudoductile fracture behavior. Bending strength was calculated from the maximum load for fracture in a load-displacement curve, and the $\mathrm{SiC}_{\mathrm{f}} / \mathrm{SiC}$ composite hot-pressed at $1700^{\circ} \mathrm{C}$ showed higher bending strength (240 MPa) than the composites hot-pressed at $1650^{\circ} \mathrm{C}$ or $1750^{\circ} \mathrm{C}$. The load-displacement curves at $1000^{\circ} \mathrm{C}$ were similar to that at room temperature. The differences in the slope at elastic deformation region in bending test at room temperature and $1000^{\circ} \mathrm{C}$ between each $\mathrm{SiC}_{\mathrm{f}} / \mathrm{SiC}$ composite were attributed to the difference in the thickness of each composite. At test temperatures above $1200^{\circ} \mathrm{C}$, the load-displacement curves were different from that at room temperature and $1000^{\circ} \mathrm{C}$. At $1200^{\circ} \mathrm{C}$ (Fig. 4(b)), the load decreased slowly after reaching the maximum load, and then the load-displacement curves spread

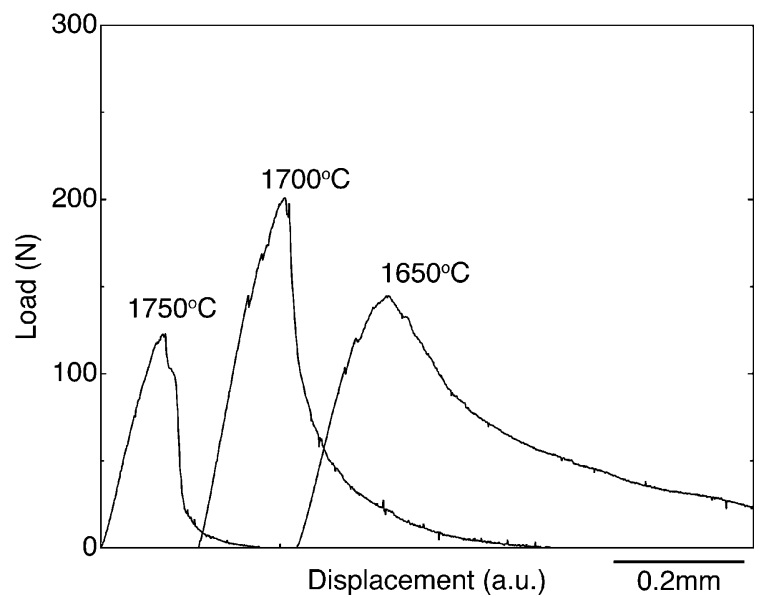

Fig. 3. Typical load-displacement curves of $\mathrm{SiC}_{\mathrm{f}} / \mathrm{SiC}$ composites fabricated by hot-pressing at $1650^{\circ} \mathrm{C}-1750^{\circ} \mathrm{C}$ in three-point bending test at room temperature. more widely rather than that at room temperature and $1000^{\circ} \mathrm{C}$. In the case of the $\mathrm{SiC}_{\mathrm{f}} / \mathrm{SiC}$ composite hot-pressed at $1650^{\circ} \mathrm{C}$, the bending strength decreased and the flat region caused by sliding between matrix and fiber cloth layer, i.e. shear fracture, was observed. At $1400^{\circ} \mathrm{C}$ (Fig. 4(c)), the bending strength decreased significantly, and the reduction in load was small after the maximum load and load-displacement curves were almost flat. These curves indicated that the $\mathrm{SiC}_{\mathrm{f}} / \mathrm{SiC}$ composites fractured in shear fracture mode at $1400^{\circ} \mathrm{C}$. The elastic deformation region in bending test became small as test temperature increased above $1200^{\circ} \mathrm{C}$. Bending strength of the $\mathrm{SiC}_{\mathrm{f}} / \mathrm{SiC}$ composite hot-pressed at $1700^{\circ} \mathrm{C}$ did not decrease up to a test temperature of $1200^{\circ} \mathrm{C}$. Fracture energy of the $\mathrm{SiC}_{\mathrm{f}} / \mathrm{SiC}$ composite hot-pressed at $1700^{\circ} \mathrm{C}$

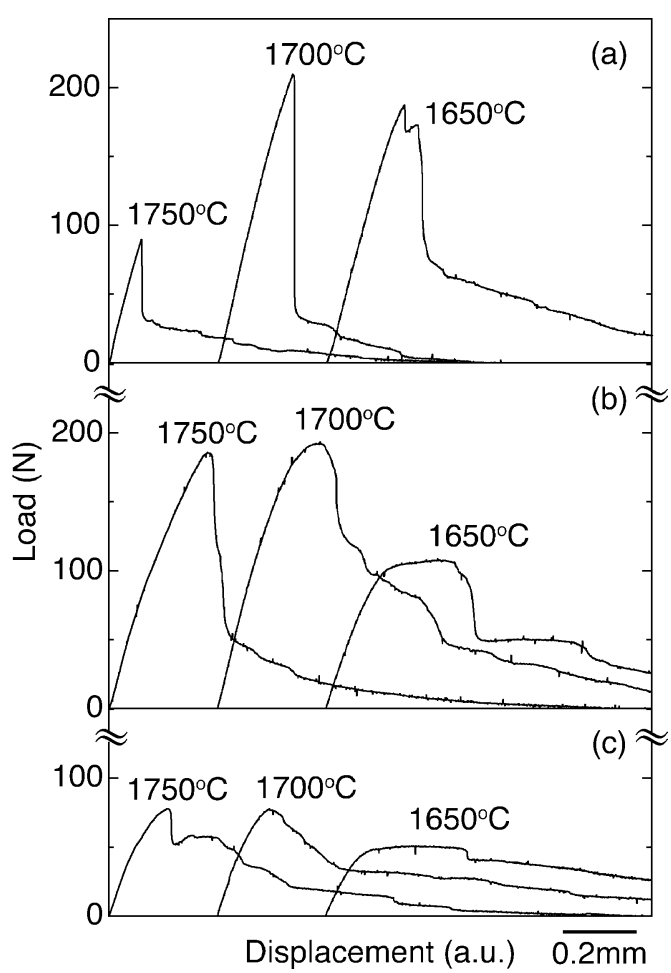

Fig. 4. Typical load-displacement curves of $\mathrm{SiC}_{\mathrm{f}} / \mathrm{SiC}$ composites fabricated by hot-pressing at $1650^{\circ} \mathrm{C}-1750^{\circ} \mathrm{C}$ in three-point bending test at (a) $1000^{\circ} \mathrm{C}$, (b) $1200^{\circ} \mathrm{C}$ and (c) $1400^{\circ} \mathrm{C}$.

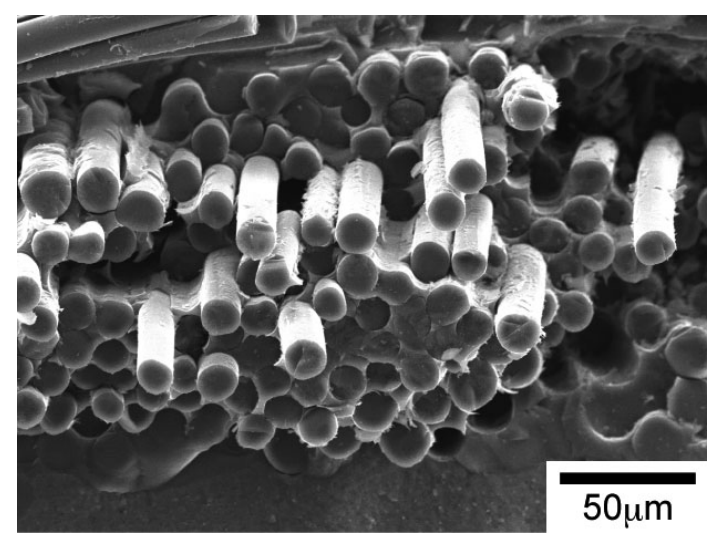

Fig. 5. SEM micrograph of fracture surface of the $\mathrm{SiC}_{\mathrm{f}} / \mathrm{SiC}$ composites fabricated by hot-pressing at $1700^{\circ} \mathrm{C}$ after three-point bending test at room temperature. 
was $4.3 \mathrm{~kJ} / \mathrm{m}^{2}$ at a test temperature of $1200^{\circ} \mathrm{C}$, and this value was four times higher than that at room temperature. These results would be attributed to an increase in crack propagation resistance and promotion of fiber pullout by the softening of the grain boundary phase in the $\mathrm{SiC}$ matrix at high temperatures. Furthermore, it was confirmed that $\mathrm{SiC}$ matrix between each filament derived from PCS impregnation acted as a protect layer and the diffusion of sintering additives into $\mathrm{SiC}$ fibers and reactions between fiber and the matrix were suppressed.

Thermal conductivity of monolithic SiC with 20 mass\% of $\mathrm{Al}_{2} \mathrm{O}_{3}-\mathrm{Y}_{2} \mathrm{O}_{3}-\mathrm{CaO}$ sintering additives hot-pressed at $1750^{\circ} \mathrm{C}$ and $\mathrm{SiC}_{\mathrm{f}} / \mathrm{SiC}$ composite fabricated by hot-pressing measured at room temperature and high temperatures up to $1000^{\circ} \mathrm{C}$ was shown in Fig. 6. ${ }^{29), 30)}$ For comparison, the change in thermal conductivity of $\mathrm{SiC}_{\mathrm{f}} / \mathrm{SiC}$ composite fabricated by CVI process (bulk density; $2.2 \mathrm{~g} / \mathrm{cm}^{3}, \mathrm{~V}_{\mathrm{f}} ; 30 \%$ ) with test temperature was also shown in Fig. $6 .{ }^{31)}$ Thermal conductivity of monolithic $\mathrm{SiC}$ was about $28 \mathrm{~W} / \mathrm{m} \cdot \mathrm{K}$ at room temperature. It decreased to $20 \mathrm{~W} / \mathrm{m} \cdot \mathrm{K}$ with increasing test temperature up to $1000^{\circ} \mathrm{C}$. Thermal conductivity of $\mathrm{SiC}_{\mathrm{f}} / \mathrm{SiC}$ composites fabricated by hot-pressing was in the range of 5 to $11 \mathrm{~W} / \mathrm{m} \cdot \mathrm{K}$ at room temperature, and it depended on their bulk density. Thermal conductivity of $\mathrm{SiC}_{\mathrm{f}} / \mathrm{SiC}$ composite tended to show a maximum at approximately $500^{\circ} \mathrm{C}$ or slightly increase with an increase in test temperature. These values were higher than that of $\mathrm{SiC}_{\mathrm{f}} / \mathrm{SiC}$ composite fabricated by CVI process reported in ref.31. From these results, dense $\mathrm{SiC}_{\mathrm{f}} / \mathrm{SiC}$ composite with excellent mechanical and thermal properties was successfully achieved by simple process using sheet stacking and hot-pressing.

\subsection{Novel fabrication process of $\mathrm{SiC}_{\mathrm{f}} / \mathrm{SiC}$ compos- ites using electrochemical process}

Recently, polycrystalline SiC fiber (Tyranno SA, Ube Industries. Ltd.) with high strength and excellent heat resistance at high temperatures has been developed. ${ }^{32)}$ Tyranno SA fiber has higher thermal conductivity of $64 \mathrm{~W} / \mathrm{m} \cdot \mathrm{K}$ at room temperature, ${ }^{33)}$ and this value is much higher than that of Hi-Nicalon fiber $\left(7.8 \mathrm{~W} / \mathrm{m} \cdot \mathrm{K}\right.$ at room temperature $\left.{ }^{34)}\right)$. These excellent properties of Tyranno SA fiber are attractive for improving mechanical and thermal properties of $\mathrm{SiC}_{\mathrm{f}} / \mathrm{SiC}$ composite, and TyrannoSA fiber has been expected to be used as the reinforcement of $\mathrm{SiC}_{\mathrm{f}} / \mathrm{SiC}$

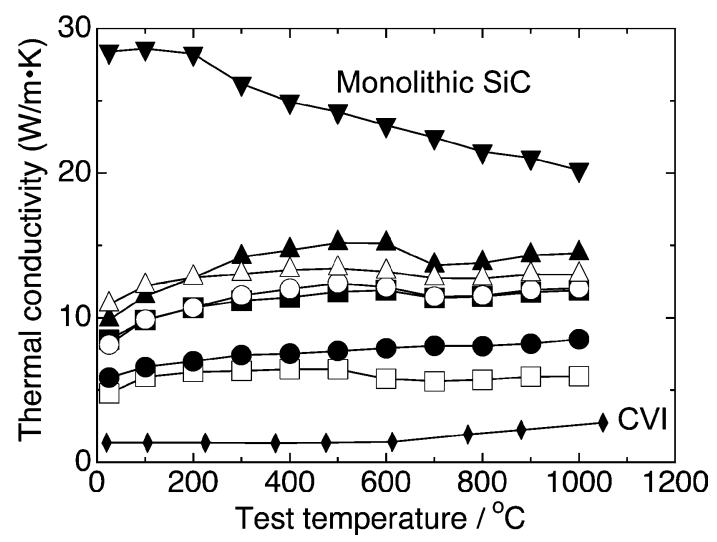

Fig. 6. Thermal conductivity of monolithic $\mathrm{SiC}$ and $\mathrm{SiC}_{\mathrm{f}} / \mathrm{SiC}$ composite fabricated by hot-pressing measured at room temperature and high temperatures up to $1000^{\circ} \mathrm{C}$. For comparison, thermal conductivity of $\mathrm{SiC}_{\mathrm{f}} / \mathrm{SiC}$ composite fabricated by CVI process ${ }^{31)}$ was also shown in this figure. Open and solid squares; hot-pressed at $1650^{\circ} \mathrm{C}$, open and solid circles; hot-pressed at $1700^{\circ} \mathrm{C}$, open and solid triangles; hot-pressed at $1750^{\circ} \mathrm{C}$. Monolithic $\mathrm{SiC}$ was hot-pressed at $1750^{\circ} \mathrm{C}$. composite. Tyranno SA fiber shows electric conductivity due to its high crystallinity, and we have paid attention to its electric conductivity, and novel fabrication process of $\mathrm{SiC}_{\mathrm{f}} / \mathrm{SiC}$ composite using electrochemical process has been proposed. ${ }^{35)-37)}$

Figure 7 shows schematic illustration of electrophoretic deposition (EPD) apparatus for carbon coating on SiC fibers and $\mathrm{SiC}$ matrix formation into $\mathrm{SiC}$ fiber cloth. Two dimensionally plainwoven polycrystalline Tyranno SA cloth was used as the reinforcement. The suspension of graphite particles for EPD was prepared using commercial colloidal graphite aqueous solution. The graphite particles had a flaky shape, and their average particle size was $400-500 \mathrm{~nm}^{36)}$ The concentration and $\mathrm{pH}$ of colloidal graphite suspension were adjusted to 0.1 mass $\%$ and 10 , respectively. The $\mathrm{SiC}$ fiber cloth and graphite plate were settled at a distance of $10 \mathrm{~mm}$ in the graphite suspension as the anode and the cathode, respectively. Graphite particles were coated on SiC fibers in the cloth by EPD using the colloidal graphite suspension under an applied voltage of $3 \mathrm{~V}$ for $10 \mathrm{~min}$, and then dried at $100^{\circ} \mathrm{C}$. SEM micrographs of as-received Tyranno SA fibers and carbon-coated SiC fibers by EPD were shown in Fig. 8. ${ }^{36)}$ As-received Tyranno SA fiber is polycrystalline, and consists of fine $\beta$-SiC particles. ${ }^{32)}$ After the carbon coating on $\mathrm{SiC}$ fibers by EPD, the surface of SiC fibers was wholly coated with flaky graphite particles. The thickness of carbon coating on $\mathrm{SiC}$ fibers was ranged from several tens to hundreds nanometers.

Submicron-sized $\beta$-SiC powder containing sintering additives consisting of $\alpha-\mathrm{Al}_{2} \mathrm{O}_{3}(14$ mass $\%), \mathrm{Y}_{2} \mathrm{O}_{3}(4$ mass $\%)$ and $\mathrm{CaCO}_{3}$ ( 2 mass $\%$ as $\mathrm{CaO}$ ) were dispersed in distilled water, and the concentration and $\mathrm{pH}$ of $\mathrm{SiC}$ suspension were adjusted to 10 mass\%

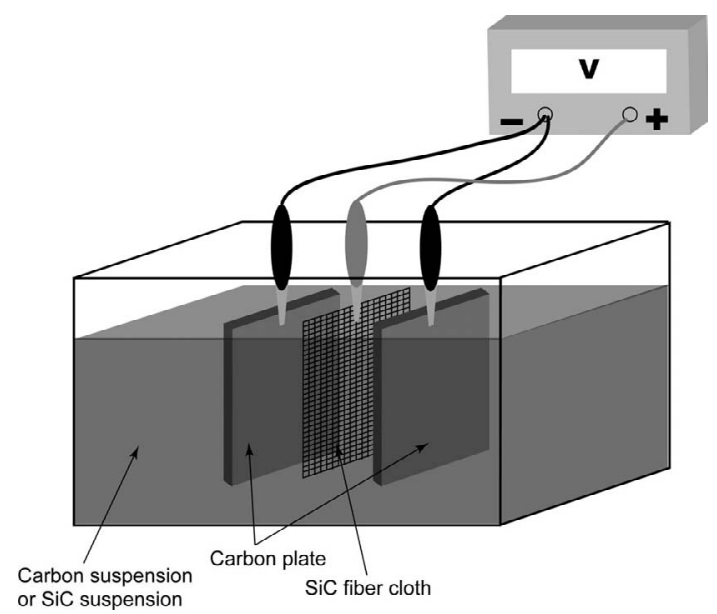

Fig. 7. Schematic illustration of electrophoretic deposition apparatus for carbon coating on $\mathrm{SiC}$ fiber cloth and infiltration of $\mathrm{SiC}$ matrix into $\mathrm{SiC}$ fiber cloth.
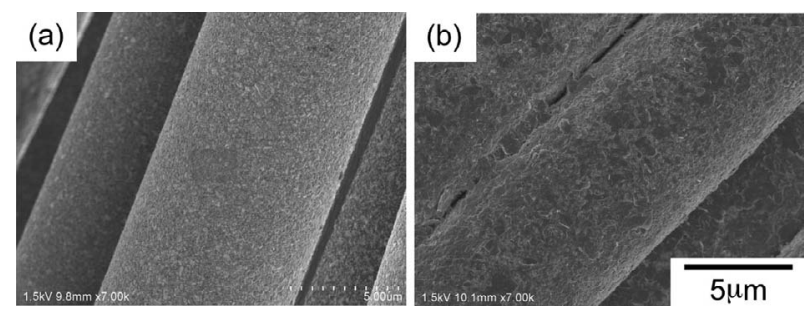

Fig. 8. SEM micrographs of the surface of (a) as-received Tyranno SA fibers and (b) carbon-coated Tyranno SA fibers by EPD. 
and 10 , respectively. The carbon-coated fiber cloth was dipped into the $\mathrm{SiC}$ suspension, and $\mathrm{SiC}$ matrix with sintering additives was infiltrated by EPD under an applied voltage of $5 \mathrm{~V}$ for $20 \mathrm{~min}$, and the cloth was dried at $100^{\circ} \mathrm{C} . \mathrm{SiC}_{\mathrm{f}} / \mathrm{SiC}$ composite was fabricated by the same process using sheet stacking and hot-pressing described in section 2.1. Hot-pressing was performed at $1700^{\circ} \mathrm{C}$ for $1 \mathrm{~h}$ in argon flow under a uniaxial pressure of $40 \mathrm{MPa}$. The $\mathrm{V}_{\mathrm{f}}$ of the $\mathrm{SiC}_{\mathrm{f}} / \mathrm{SiC}$ composite fabricated in this process was $52 \%$, and its bulk density and open porosity were $2.8 \mathrm{~g} / \mathrm{cm}^{3}$ and $9.3 \%$, respectively.

SEM micrographs of the cross section of $\mathrm{SiC}_{\mathrm{f}} / \mathrm{SiC}$ composite using carbon-coated $\mathrm{SiC}$ fibers by EPD are shown in Fig. 9. ${ }^{37)}$ Thin carbon coating was formed on $\mathrm{SiC}$ fibers, and $\mathrm{SiC}$ matrix was formed sufficiently between each fiber filament by EPD. Figure 10 shows typical load-displacement curves of the $\mathrm{SiC}_{\mathrm{f}} /$ $\mathrm{SiC}$ composite fabricated by EPD in three-point bending test at

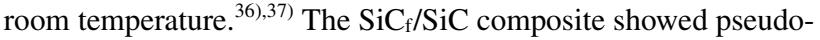
ductile fracture behavior with fiber pullout, and average bending strength of the $\mathrm{SiC}_{\mathrm{f}} / \mathrm{SiC}$ composite was $117 \mathrm{MPa}$. In consideration of fracture behavior and fracture surface of the $\mathrm{SiC}_{\mathrm{f}} / \mathrm{SiC}$ composite, it seemed that the optimum interface between the fiber and their matrix was obtained by EPD under this condition.

The principle of EPD process for the formation of SiC matrix and carbon coating would be considered as follows; ${ }^{36)}$ negatively charged graphite particles were coated well on positively charged $\mathrm{SiC}$ fibers, and carbon coating on $\mathrm{SiC}$ fibers was relatively homogeneous. Furthermore, graphite particles were infiltrated into fiber bundle by electrical force, and then relatively homogeneous carbon coating was formed not only on $\mathrm{SiC}$ fibers at the surface of the bundle but also on fibers at the center of the bundle. Matrix components, $\beta$-SiC, $\mathrm{Al}_{2} \mathrm{O}_{3}, \mathrm{Y}_{2} \mathrm{O}_{3}$ and $\mathrm{CaCO}_{3}$ parti-
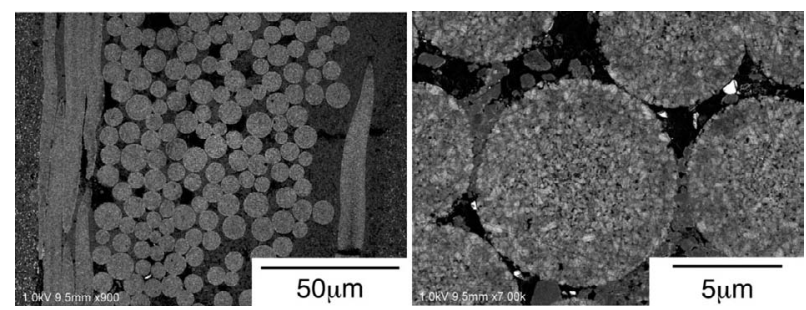

Fig. 9. SEM micrographs of the cross section of $\mathrm{SiC}_{\mathrm{f}} / \mathrm{SiC}$ composite using carbon-coated Tyranno SA fiber cloths by EPD.

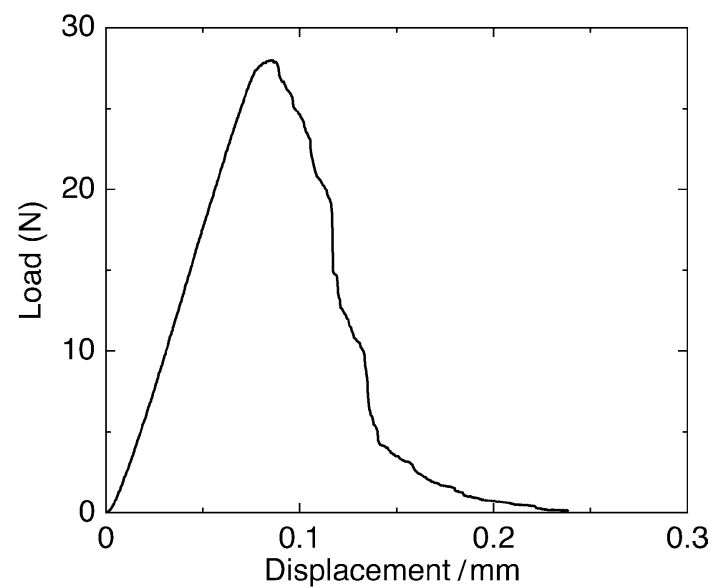

Fig. 10. Typical load-displacement curves of $\mathrm{SiC}_{\mathrm{f}} / \mathrm{SiC}$ composites fabricated by EPD in three-point bending test at room temperature. cles, would be also negatively charged and dispersed under this suspension condition in consideration of their iso-electric point, and these matrix components were infiltrated into fiber bundles by electric force.

We have demonstrated that EPD process is expected to be an effective way to control the fiber/matrix interface and the microstructure of $\mathrm{SiC}_{\mathrm{f}} / \mathrm{SiC}$ composite with high performance, and it will become an industrially useful process that leads to production of structural parts with large and complicated shape, reduction of production cost, and better productivity in the future. Furthermore, it is expected that EPD process can be applied for not only $\mathrm{SiC}_{\mathrm{f}} / \mathrm{SiC}$ composite but also other fiberreinforced ceramic matrix composites by the optimization of EPD conditions.

\section{Modeling and analysis of mechanical and ther- mal properties of $\mathrm{SiC}_{f} / \mathrm{SiC}$ composite}

\subsection{Quantitative analysis of interfacial properties} of $\mathrm{SiC}_{\mathrm{f}} / \mathrm{SiC}$ composite by push-in test

Mechanical properties of fiber-reinforced ceramic matrix composite strongly depend on their interfacial properties between fiber and the matrix, and it is important for the material design of fiber-reinforced ceramic matrix composite with high mechanical properties and the optimization of its fabrication process to evaluate the interfacial properties quantitatively and to clarify the relation between interfacial properties and mechanical properties of the composite.

There are several methods for evaluating interfacial shear stress including debonding and sliding of fiber-reinforced ceramic matrix composite such as push-out test ${ }^{38), 39)}$ and push-in test. $^{40)-43)}$ Push-in test is a method to measure interfacial strength of fiber-reinforced ceramic matrix composite by pushing the fiber into the matrix along with fiber axis by indenter. Present authors performed push-in test using nanoindenter that can control applied load accurately by milligram order during loading and measure applied load and displacement of the indenter continuously for evaluating interfacial properties of $\mathrm{SiC}_{\mathrm{f}} / \mathrm{SiC}$ composite quantitatively and investigated the relation between their interfacial properties and mechanical properties.

Interfacial properties of the $\mathrm{SiC}_{\mathrm{f}} / \mathrm{SiC}$ composites using $\mathrm{Hi}-$ Nicalon fibers fabricated by CVI process (CVI-composite) ${ }^{18)}$ and hot-pressing (HP-composite) ${ }^{24)}$ were evaluated by push-in test using a dynamic ultra-microhardness tester with a triangle indenter. Maximum load and loading rate were $0.2 \mathrm{~N}$ and $5 \mathrm{mN} /$ sec, respectively. Specimens for push-in test were cut from the $\mathrm{SiC}_{\mathrm{f}} / \mathrm{SiC}$ composite, and their surface perpendicular to fiber axis was mirror-polished. True fiber displacement $(u)$ was calculated by subtracting the penetration depth of indenter $\left(u_{0}\right)$ into the fiber from total displacement of indenter $\left(u_{\mathrm{t}}\right)$. Figure 11 shows the schematic illustration of push-in test and appearance of fiber in $\mathrm{SiC}_{\mathrm{f}} / \mathrm{SiC}$ composite after push-in test. ${ }^{44)}$ Interfacial shear sliding strength $\left(\tau_{\mathrm{s}}\right)$ was determined by the following equation reported by Marshall; ${ }^{40)}$

$$
\tau_{\mathrm{s}}=\frac{F^{2}}{4 \pi^{2} u r_{\mathrm{f}}^{3} E_{\mathrm{f}}}
$$

where $F$ is applied load, $u$ true fiber displacement, $r_{\mathrm{f}}$ fiber radius and $E_{\mathrm{f}}$ elastic modulus of fiber. By plotting the square of load versus true fiber displacement, $\tau_{\mathrm{s}}$ was calculated from the slope of loading region in the square of load-true fiber displacement curve. Debonding strength $\left(\sigma_{\mathrm{d}}\right)$ was simply calculated from the following equation; 


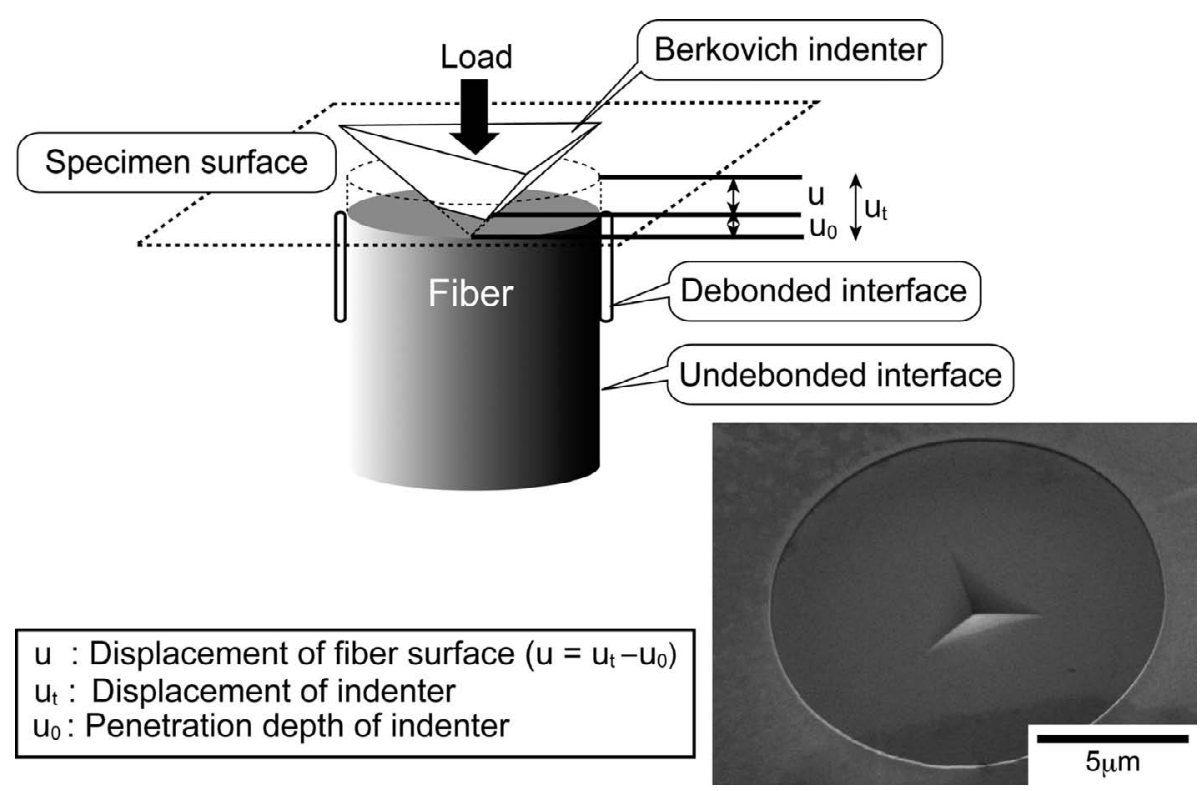

Fig. 11. Schematic illustration of push-in test and appearance of fiber after push-in test.
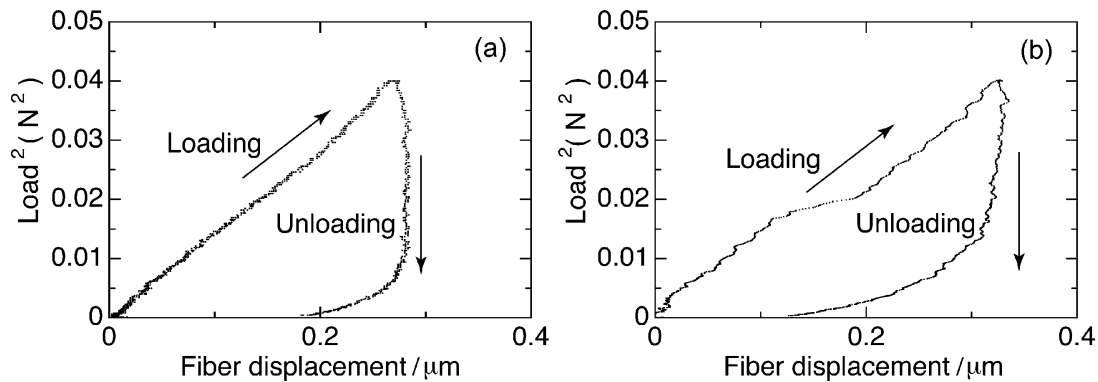

Fig. 12. Typical square of load-true fiber displacement curves of $\mathrm{SiC}_{\mathrm{f}} / \mathrm{SiC}$ composites fabricated by (a) CVI process and (b) hot-pressing in push-in test.

Table 1. Interfacial Shear Sliding Strength $\left(\tau_{\mathrm{s}}\right)$, Debonding Strength $\left(\sigma_{\mathrm{d}}\right)$, Fiber Pullout Length $\left(l_{\mathrm{p}}\right)$, Energy of a Single Fiber Pullout $\left(\gamma_{\mathrm{p}}\right)$, Three-Point Bending Strength $\left(\sigma_{3 \mathrm{p}}\right)$ and Fracture Energy $(\Gamma)$ of the $\mathrm{SiC}_{\mathrm{f}} / \mathrm{SiC}$ Composites Measured at Room Temperature

\begin{tabular}{lcccccc}
\hline \multicolumn{1}{c}{ Specimen } & $\tau_{\mathrm{s}}(\mathrm{MPa})$ & $\sigma_{\mathrm{d}}(\mathrm{Mpa})$ & $\sigma_{3 \mathrm{p}}(\mathrm{MPa})$ & $\Gamma\left(\mathrm{J} / \mathrm{m}^{2}\right)$ & $l_{\mathrm{p}}(\mu \mathrm{m})$ & $\gamma_{\mathrm{p}}(\mathrm{J})$ \\
\hline CVI-composite & $45 \pm 23$ & $215 \pm 120$ & 390 & 6600 & $245 \pm 221$ & $1.1 \times 10^{-4}$ \\
HP-composite $\left(1650^{\circ} \mathrm{C}^{*}\right)$ & $53 \pm 46$ & $185 \pm 145$ & 180 & 2250 & $518 \pm 345$ & $4.5 \times 10^{-4}$ \\
HP-composite $\left(1700^{\circ} \mathrm{C}^{*}\right)$ & $62 \pm 50$ & $145 \pm 140$ & 250 & 1120 & $218 \pm 167$ & $1.0 \times 10^{-4}$ \\
HP-composite $\left(1750^{\circ} \mathrm{C}^{*}\right)$ & $80 \pm 46$ & $165 \pm 145$ & 180 & 470 & $52 \pm 46$ & $8.4 \times 10^{-6}$ \\
\hline
\end{tabular}

*Sintering temperature

$$
\sigma_{\mathrm{d}}=\frac{F_{\mathrm{d}}}{\pi r_{\mathrm{f}}^{2}}
$$

where $F_{\mathrm{d}}$ is the debonding load. The work done by pullout of a single fiber $\left(\gamma_{\mathrm{p}}\right)$ was calculated by the following equation;

$$
\gamma_{\mathrm{p}}=2 \pi r_{\mathrm{f}} \tau_{\mathrm{s}} \int_{0}^{\mathrm{l}_{\mathrm{p}}} l_{\mathrm{f}} d l=\pi r_{\mathrm{f}} \tau_{\mathrm{s}} l_{\mathrm{p}}^{2}
$$

where $l_{\mathrm{f}}$ is fiber length and $l_{\mathrm{p}}$ fiber pullout length. Fiber pullout length $\left(l_{\mathrm{p}}\right)$ in $\mathrm{SiC}_{\mathrm{f}} / \mathrm{SiC}$ composite after bending test was measured by SEM observation.

Figure 12 shows typical square of load-true fiber displacement curves of CVI- and HP-composites in push-in test. ${ }^{12)}$ The
CVI-composite mainly showed a linear loading curve, which would suggest constant $\tau_{\mathrm{s}}$. In contrast, the HP-composite showed a non-linear curve in many fibers. This result would indicate that $\tau_{\mathrm{s}}$ changed along the fiber due to the residual stress caused by shrinkage of SiC matrix during hot-pressing, and the formation of rough interface by thermal and chemical effect of polycarbosilane and liquid phase derived from sintering additives.

Interfacial and mechanical properties of CVI- and HPcomposites are listed in Table 1. ${ }^{12)}$ The $\tau_{\mathrm{s}}$ of the CVI-composite was $45 \pm 23 \mathrm{MPa}$. In consideration of the results reported by Licciulli et al. ${ }^{42)}$ and Lowden et al., ${ }^{43)}$ our results obtained in the CVI-composite would be appropriate values. The HP-composites 
showed higher $\tau_{\mathrm{s}}$ than that of the CVI- composite. The mean $\tau_{\mathrm{s}}$ of the HP-composite increased with increasing hot-pressing temperature. The $\sigma_{\mathrm{d}}$ of the CVI-composite was slightly higher than that of the HP-composite, and the HP-composite at $1700^{\circ} \mathrm{C}$ showed the lowest $\sigma_{\mathrm{d}}$. However, the difference in $\sigma_{\mathrm{d}}$ was small among them in consideration of the scatter of data.

Bending strength and fracture energy of the CVI-composite was higher than those of the HP-composites due to lower interfacial shear sliding strength and higher fiber strength. It was reported that the original tensile strength of Hi-Nicalon fiber after thermal exposure in argon atmosphere is maintained up to $1400^{\circ} \mathrm{C}$, and it decreases gradually above $1400^{\circ} \mathrm{C}^{45)}$ The processing temperature of CVI was lower than that of hot-pressing, resulting in higher fiber strength in the $\mathrm{SiC}_{\mathrm{f}} / \mathrm{SiC}$ composite fabricated by CVI process. The HP-composite at $1750^{\circ} \mathrm{C}$ had a higher $\tau_{\mathrm{s}}$ and lower fiber strength. High $\tau_{\mathrm{s}}$ causes an increase in sliding resistance at the interface, which induces the difficulty in fiber pullout, and a fiber with lower strength fractures easily, resulting in low bending strength and fracture energy. In fact, $l_{\mathrm{p}}$ was so short and $\gamma_{p}$ was so small compared with the CVIcomposites or HP-composites at $1650^{\circ} \mathrm{C}$ and $1700^{\circ} \mathrm{C}$. The HPcomposite at $1650^{\circ} \mathrm{C}$ showed a lower bending strength and higher fracture energy in spite of a lower $\tau_{\mathrm{s}}$, higher fiber strength, larger $l_{\mathrm{p}}$ and $\gamma_{\mathrm{p}}$. In this case, strengthening of SiC matrix is not enough due to the lower sintering temperature, and then delamination between fiber cloth layers and $\mathrm{SiC}$ matrix occurs easily. The quantitative results on interfacial properties of the $\mathrm{SiC}_{\mathrm{f}} / \mathrm{SiC}$ composites well agreed with the results on their mechanical properties. Base on these results, material design of the $\mathrm{SiC}_{\mathrm{f}} / \mathrm{SiC}$ composite with high mechanical properties and optimization of its fabrication process was achieved.

\subsection{Modeling and material design for improve- ment of the thermal conductivity of $\mathrm{SiC}_{\mathrm{f}} / \mathrm{SiC}$ composite}

For some applications such as structural parts in fusion reactors and high-temperature gas turbine, higher thermal conductivity of the $\mathrm{SiC}_{\mathrm{f}} / \mathrm{SiC}$ composite is needed in addition to its higher mechanical strength and fracture toughness. Thermal conductivity of the $\mathrm{SiC}_{\mathrm{f}} / \mathrm{SiC}$ composite would depend on not only the thermal conductivity of each component such as $\mathrm{SiC}$ matrix and $\mathrm{SiC}$ fibers but also microstructure of the composite. Present authors have improved the thermal conductivity of $\mathrm{SiC}$ matrix by the microstructure control using coarse $\mathrm{SiC}$ grains. ${ }^{46)}$ It is experimentally well-known that the thermal conductivity of polycrystalline ceramics increases with an increase in their grain size and it increases in proportion to the square root of the average grain size. ${ }^{47)}$ Fiber-reinforced composite has a complicated structure, and its analytical thermal conductivity model becomes very sophisticated because the effects of not only fibers and matrix but also interfaces and pores on the thermal conductivity of the composite must be considered. Up to now, some analytical thermal conductivity models of fiber-reinforced composites taking into account the effects of interfacial layers and fibers on their thermal conductivity have been reported. ${ }^{48)-50)}$ The porosity of the $\mathrm{SiC}_{\mathrm{f}} / \mathrm{SiC}$ composite obtained by our process was very small (open porosity; $1.0-1.5 \%$ ) compared with that of conventional composite fabricated by CVI and PIP processes. As for fiber cloth layers in the composite, it was considered that the effect of the $\mathrm{SiC}$ matrix formed in fiber cloths was probably more dominant than that of interfaces between fiber and the matrix. Therefore, the present $\mathrm{SiC}_{\mathrm{f}} / \mathrm{SiC}$ composites were assumed to be a simple multilayered structure consisting of fiber cloth layers with
$\mathrm{SiC}$ matrix and $\mathrm{SiC}$ matrix layers derived from $\mathrm{SiC}$ sheets without any consideration of the effects of pores and interfaces on their thermal conductivity. Based on our experimental data, it was demonstrated that the thermal conductivity of the $\mathrm{SiC}_{\mathrm{f}} / \mathrm{SiC}$ composite fabricated by sheet stacking and hot-pressing could be simply approximated by series model of multilayered structure. ${ }^{46)}$ From this approximation, we focused on microstructure control of $\mathrm{SiC}_{\mathrm{f}} / \mathrm{SiC}$ composite using polycrystalline $\mathrm{SiC}$ fiber with high thermal conductivity, and improvement of thermal conductivity of $\mathrm{SiC}_{\mathrm{f}} / \mathrm{SiC}$ composite was investigated.

Green sheet consisting of submicron-sized $\alpha$-SiC powder containing 20 mass $\%$ of micron-sized $\alpha$-SiC powder and $\mathrm{Al}_{2} \mathrm{O}_{3}-$ $\mathrm{Y}_{2} \mathrm{O}_{3}-\mathrm{CaO}$ system (20 mass $\%$ in total) was prepared by laboratoryscale tape casting equipment. Two-dimensionally plain-woven Tyranno SA fiber cloth was used as the reinforcement. Carbon coating on $\mathrm{SiC}$ fibers was formed by $\mathrm{EPD}$ process. ${ }^{36,37)} \mathrm{SiC}$ matrix between each filament was formed by EPD process using $\mathrm{SiC}$ powder suspension or PCS impregnation. These SiC cloths and $\mathrm{SiC}$ green sheets were stacked alternately, and then heattreated at $300^{\circ} \mathrm{C}$. The compact was hot-pressed at $1750^{\circ} \mathrm{C}$ for $1 \mathrm{~h}$ in argon flow under a uniaxial pressure of $40 \mathrm{MPa}$. $\mathrm{The}^{\mathrm{SiC}} \mathrm{f} / \mathrm{SiC}$ composites using the $\mathrm{SiC}$ cloth treated by EPD and PCS were presented as EPD-composite and PCS-composite, respectively. For comparison, the $\mathrm{SiC}_{\mathrm{f}} / \mathrm{SiC}$ composite was fabricated by hotpressing using untreated TyrannoSA fiber cloth and $\mathrm{SiC}$ green sheet (this composite was presented as Untreated composite). Thermal conductivity of the composite was measured perpendicular to the cloth layers at room temperature by laser flash method.

Monolithic $\alpha$-SiC containing 20 mass $\%$ of coarse $\alpha$-SiC grains and $\mathrm{Al}_{2} \mathrm{O}_{3}-\mathrm{Y}_{2} \mathrm{O}_{3}-\mathrm{CaO}$ sintering additives was hot-pressed under the same condition as the $\mathrm{SiC}_{\mathrm{f}} / \mathrm{SiC}$ composite, and its thermal conductivity was $54 \mathrm{~W} / \mathrm{m} \cdot \mathrm{K}$ at room temperature.

Table 2 shows fiber volume fraction, bulk density, open porosity and thermal conductivity of the $\mathrm{SiC}_{\mathrm{f}} / \mathrm{SiC}$ composites. The thermal conductivity of PCS-composite was $18 \mathrm{~W} / \mathrm{m} \cdot \mathrm{K}$. This value was higher than that of the composite fabricated in our previous study, ${ }^{24), 29)}$ but a significant increase in thermal conductivity was not achieved. On the other hand, the thermal conductivity of EPD-composite and untreated composite was $45 \mathrm{~W} / \mathrm{m} \cdot \mathrm{K}$ and $56 \mathrm{~W} / \mathrm{m} \cdot \mathrm{K}$, respectively, and these values were much higher than that of the $\mathrm{SiC}_{\mathrm{f}} / \mathrm{SiC}$ composite reported in our previous paper $^{24), 29)}$ and PCS-composite described above.

Figure 13(a) shows the schematic illustration of a rule of mixtures in multilayered structures. ${ }^{46)}$ Thermal conductivity of the multilayered structures in the directions parallel $\left(\kappa_{\mathrm{c} l}\right.$, parallel model) and perpendicular $\left(\kappa_{\mathrm{c} 2}\right.$, series model) to the layer, i.e. fiber cloth alignment, can be simply given by

$$
\begin{aligned}
& \kappa_{\mathrm{c} 1}=\kappa_{\mathrm{f}} V_{\mathrm{f}}+\kappa_{\mathrm{m}} V_{\mathrm{m}} \\
& \frac{1}{\kappa_{\mathrm{c} 2}}=\frac{V_{\mathrm{f}}}{\kappa_{\mathrm{f}}}+\frac{V_{\mathrm{m}}}{\kappa_{\mathrm{m}}}
\end{aligned}
$$

where $\kappa_{\mathrm{m}}$ and $\kappa_{\mathrm{f}}$ are the thermal conductivity of the matrix and fibers, $V_{m}$ and $V_{f}$ volume fraction of matrix and fibers, respectively. Assuming that the $\kappa_{\mathrm{f}}$ of Tyranno SA is $60 \mathrm{~W} / \mathrm{m} \cdot \mathrm{K}$ and the $\kappa_{\mathrm{m}}$ is 30,54 and $60 \mathrm{~W} / \mathrm{m} \cdot \mathrm{K}(54 \mathrm{~W} / \mathrm{m} \cdot \mathrm{K}$ and $60 \mathrm{~W} / \mathrm{m} \cdot \mathrm{K}$ is corresponding to the values of $\mathrm{SiC}$ matrix and Tyranno SA fibers, respectively), the thermal conductivities of the composite calculated by Eq. (4) and Eq. (5) as a function of fiber volume fraction are shown in Fig. 13(b). Untreated composite had a multilayered structure consisting of polycrystalline $\mathrm{SiC}$ fiber cloths and $\mathrm{SiC}$ matrices derived from $\mathrm{SiC}$ sheet, and its thermal conductivity 
Table 2. Fiber Volume Fraction, Bulk Density, Open Porosity and Thermal Conductivity of the $\mathrm{SiC}_{\mathrm{f}} / \mathrm{SiC} \mathrm{Composites}_{\mathrm{C}}$

\begin{tabular}{lcccc}
\hline \multicolumn{1}{c}{ Specimen } & Fiber volume fraction (\%) & Bulk density $\left(\mathrm{g} / \mathrm{cm}^{3}\right)$ & Open porosity $(\%)$ & Thermal conductivity $(\mathrm{W} / \mathrm{m} \cdot \mathrm{K})$ \\
\hline EPD-composite & 41.9 & 3.12 & 1.43 & 44.5 \\
PCS-composite & 38.4 & 2.97 & 1.06 & 18.3 \\
Untreated composite & 50.9 & 3.14 & 1.36 & 56.1 \\
\hline
\end{tabular}

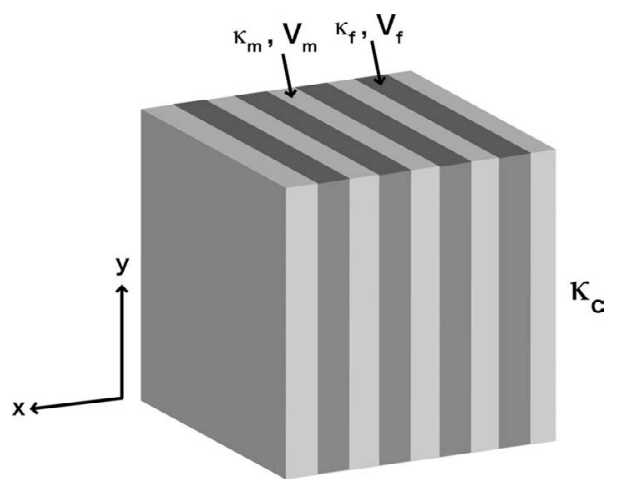

(a)

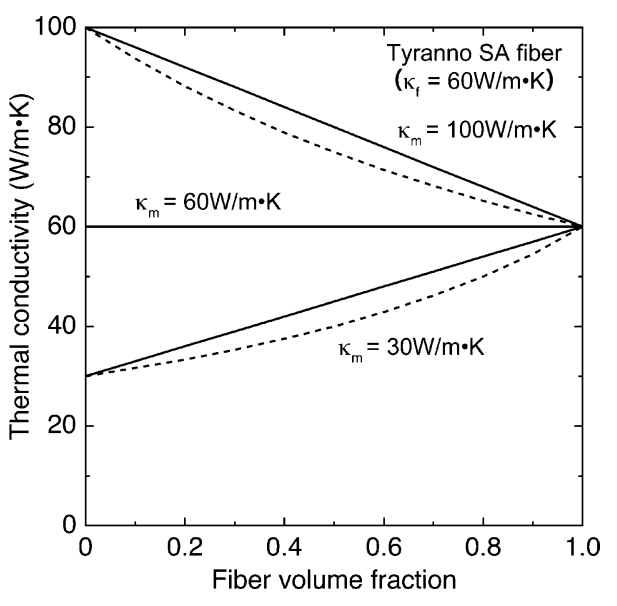

(b)

Fig. 13. (a) Schematic illustration of a rule of mixtures in multilayered structures, (b) Relation between fiber volume fraction and thermal conductivity of the multilayered structure calculated by Eqs. (4)(straight line) and (5) (broken line).

well agreed with the ideal thermal conductivity calculated by series model using $\kappa_{\mathrm{m}}(54 \mathrm{~W} / \mathrm{m} \cdot \mathrm{K})$ in Fig. 13(b). In the case of PCS-composite, the $\mathrm{SiC}$ matrix formed in $\mathrm{SiC}$ fiber cloths was derived from PCS, and this matrix shows lower thermal conductivity due to its low crystallinity. PCS-impregnated SiC fiber cloths would act as the layer with low thermal conductivity since the low thermal conductivity of PCS-derived SiC matrix would be dominant to that of the cloth layers. As a result, the thermal conductivity of PCS-composite would be very low. EPDcomposite had a thermal conductivity of $45 \mathrm{~W} / \mathrm{m} \cdot \mathrm{K}$, and this value was slightly lower than the value calculated by series model. This difference in thermal conductivity would be caused by the interfacial condition between $\mathrm{SiC}$ matrix and fibers. Higher thermal conductivity of $\mathrm{SiC}_{\mathrm{f}} / \mathrm{SiC}$ composite was successfully achieved by microstructure control, and the thermal conductivity of the $\mathrm{SiC}_{\mathrm{f}} / \mathrm{SiC}$ composite will approach the value of untreated composite in maximum by the optimization of the fabrication process of $\mathrm{SiC}_{\mathrm{f}} / \mathrm{SiC}$ composite.

\section{Conclusions}

This paper reviews novel fabrication process of continuous $\mathrm{SiC}_{\mathrm{f}} / \mathrm{SiC}$ composites with high performance based on interfacial and microstructure control and our approach to improvement of mechanical and thermal properties of $\mathrm{SiC}_{\mathrm{f}} / \mathrm{SiC}$ composite based on modeling and analysis.

The present authors developed the simple fabrication process of two-dimensional $\mathrm{SiC}_{\mathrm{f}} / \mathrm{SiC}$ composite using sheet stacking and hot-pressing based on interfacial and microstructure control, and dense $\mathrm{SiC}_{\mathrm{f}} / \mathrm{SiC}$ composite with excellent mechanical and thermal properties was successfully obtained. Furthermore, novel fabrication process of $\mathrm{SiC}_{\mathrm{f}} / \mathrm{SiC}$ composite using EPD process was proposed and it was demonstrated that EPD process is expected to be an effective way to control the fiber/matrix interface and the microstructure of $\mathrm{SiC}_{\mathrm{f}} / \mathrm{SiC}$ composite with high perfor- mance, and it will become an industrially useful process that leads to production of structural parts with large and complicated shape, reduction of production cost, and better productivity in the future. This process is also expected to be applied for not only $\mathrm{SiC}_{\mathrm{f}} / \mathrm{SiC}$ composite but also other fiber-reinforced ceramic matrix composites.

Interfacial properties of $\mathrm{SiC}_{\mathrm{f}} / \mathrm{SiC}$ composite such as interfacial shear sliding strength and interfacial debonding strength were quantitatively evaluated by push-in test using nanoindenter, and these quantitative results well agreed with the results on their mechanical properties. From these results, material design of the $\mathrm{SiC}_{\mathrm{f}} / \mathrm{SiC}$ composite with high mechanical properties and optimization of its fabrication process could be suggested. Simple model of thermal conductivity of $\mathrm{SiC}_{\mathrm{f}} / \mathrm{SiC}$ composite based on series model of multilayered structure was suggested by our experimental data, and improvement of thermal conductivity of $\mathrm{SiC}_{\mathrm{f}} / \mathrm{SiC}$ composite was investigated. As a result, higher thermal conductivity of $\mathrm{SiC}_{\mathrm{f}} / \mathrm{SiC}$ composite was successfully achieved by microstructure control.

Acknowledgements The author is deeply grateful to Prof. Toyohiko Yano, Prof. Emeritus Takayoshi Iseki and Mr. Masamitsu Imai (Tokyo Tech.) for their kind support, and helpful suggestions and discussions. The author also acknowledges the contributions of all of the co-authors described in our original papers.

\section{References}

1) T. P. Harbell and W. A. Sanders, "Flight-Vehicle Materials, Structures and Dynamics-Assessment and Future Directions, Vol. 3," Ed. by S. R. Levine, The American Society of Mechanical Engineers, New York (1992) pp. 19-41.

2) T. J. Whalen, Ceram. Eng. Sci. Proc., 7, 1135-1143 (1986).

3) J. H. Rovner and G. R. Hopkins, Nucl. Technol., 29, 274-302 (1976). 
4) G. R. Hopkins and R. J. Price, Nucl. Eng. Des. Fusion, 2, 111143 (1985).

5) H. Kaya, Compos. Sci. Technol., 59, 861-872 (1999).

6) L. Giancarli, G. Aiello, A. Caso, A. Gasse, G. Le Marois, Y. Poitevin, J. F. Salavy and J. Szczepanski, Fusion Eng. Des., 48, 509-520 (2000).

7) T. Ogasawara, J. Plasma Fusion Res., 80, 36-41 (2004) [in Japanese].

8) K. Niihara, Ceramics, 26, 457-462 (1991) [in Japanese].

9) M. Sakai, J. Soc. Mater. Sci. Japan, 44, 138-143 (1995) [in Japanese].

10) F. W. Zok, A. G. Evans and T. J. Mackin, "Handbook on Continuous Fiber-Reinforced Ceramic Matrix Composites," Ed. by R. L. Lehman, S. K. El-Rahaiby and J. B. Wachtman Jr., Purdue University, West Lafeyette and The American Ceramic Society, Weterville (1995) pp. 35-110.

11) T. Yano and K. Yoshida, Expected Materials for the Future, 9, 22-32 (2009) [in Japanese].

12) T. Yano and K. Yoshida, Strength, Fracture and Complexity, 1, 157-165 (2003).

13) R. Naslain, Compos. Interfaces, 1, 253-286 (1993).

14) Y. Kagawa, Ceram. Trans., 99, 179-185 (1998).

15) A. Saeki, M. Takeda, A. Yokoyama and T. Yoshida, Ceram. Eng. Sci. Proc., 21, 363-370 (2000).

16) P. J. Geoghegan, "Flight-Vehicle Materials, Structures and Dynamics-Assessment and Future Directions, Vol. 3, Ceramic Matrix Composites," Ed. by S. R. Lavine, The American Society of Mechanical Engineers, New York (1992) pp. 113-137.

17) F. I. Hurwitz, "Flight-Vehicle Materials, Structures and Dynamics-Assessment and Future Directions, Vol. 3, Ceramic Matrix Composites," Ed. by S. R. Lavine, The American Society of Mechanical Engineers, New York (1992) pp. 59-77.

18) K. Yoshida, M. Imai and T. Yano, J. Ceram. Soc. Japan, 108, 224-229 (2000).

19) T. Kameda and Y. Itoh, Key Eng. Mater., 164-165, 95-98 (1999).

20) J. D. Hong, M. H. Hong and P. F. Davis, Ceram. Int., 5, 155160 (1979)

21) M. Mitomo, Y. W. Kim and H. Hirotsuru, J. Mater. Res., 11, 1601-1604 (1996)

22) T. Yano, Y. Yamamoto and K. Yoshida, Key Eng. Mater., 166, 135-138 (1999)

23) K. Yoshida, M. Imai and T. Yano, Key Eng. Mater., 164-165, 217-220 (1999)

24) K. Yoshida, M. Imai and T. Yano, Compos. Sci. Technol., 61, 1323-1329 (2001).

25) K. Yoshida, Budiyanto, M. Imai and T. Yano, J. Nucl. Mater., 258-263, 1960-1965 (1998)

26) K. Okamura, Ceramics, 31, 483-487 (1996) [in Japanese].
27) M. Narisawa, M. Shimoda, K. Okamura, M. Sugimoto and T. Seguchi, Bull. Chem. Soc. Japan, 68, 1098-1104 (1995).

28) K. Kakimoto, F. Wakai, J. Bill and F. Aldinger, J. Am. Ceram. Soc., 82, 2337-2341 (1999).

29) K. Yoshida and T. Yano, J. Nucl. Mater., 283-287, 560-564 (2000).

30) K. Yoshida, M. Imai and T. Yano, J. Ceram. Soc. Japan, 109, 863-867 (2001).

31) R. Yamada, T. Taguchi, J. Nakano and N. Igawa, Ceram. Eng. Sci. Proc., 20, 273-280 (1999).

32) T. Ishikawa, Y. Kohtoku, K. Kumagawa, T. Yamamura and T. Nagasawa, Nature, 391, 773-775 (1998).

33) T. Ishikawa, S. Kajii and T. Hisayuki, Ceram. Eng. Sci. Proc., 21, 323-330 (2000).

34) A. Urano, M. Sakamoto, M. Takeda, Y. Imai, H. Araki and T. Noda, Ceram. Eng. Sci. Proc., 19, 55-63 (1998).

35) K. Yoshida, H. Matsumoto, M. Imai, K. Hashimoto, Y. Toda and T. Yano, Key Eng. Mater., 352, 77-80 (2007).

36) K. Yoshida, K. Matsukawa, M. Imai and T. Yano, Mater. Sci. Eng. B, 161, 188-192 (2009).

37) K. Yoshida, K. Matsukawa and T. Yano, J. Nucl. Mater., 386388, 643-646 (2009).

38) R. J. Kerans, R. S. Hay and N. J. Pagano, Ceram. Bull., 68, 429-442 (1989).

39 J. D. Bright, D. K. Shetty, C. W. Griffin and S. Y. Limaye, J. Am. Ceram. Soc., 72, 1891-1898 (1989).

40) D. B. Marshall, J. Am. Ceram. Soc., 67, C259-C260 (1984).

41) D. B. Marshall and W. C. Oliver, J. Am. Ceram. Soc., 70, 542548 (1987)

42) A. Licciulli, F. De Riccardis, A. Quirini, C. A. Nannetti, G. Filacchioni, L. Pilloni, S. Botti, A. Ortona and A. Cammarota, Key Eng. Mater., 127-131, 279-286 (1997).

43) R. A. Lowden and D. P. Stinton, Ceram. Eng. Sci. Proc., 9, 705-722 (1988).

44) K. Yoshida, T. Yano and T. Iseki, The Technology of Fusion Energy, 39, 607-611 (2001).

45) M. Takeda, J. Sakamoto, Y. Imai and H. Ichikawa, Compos. Sci. Technol., 59, 813-819 (1999).

46) K. Yoshida, M. Imai and T. Yano, "High Temperature Ceramic Matrix Composites," Ed. by W. Krenkel, R. Naslain and H. Schneider, Wiley-VCH, Weinheim (2001) pp. 381387.

47) H. J. Goldsmid and A. W. Penn, Phys. Lett., 27A, 523-524 (1968).

48) A. J. Markworth, J. Mater. Sci. Lett., 12, 1487-1489 (1993).

49) T. D. Fadale and M. Taya, J. Mater. Sci. Lett., 10, 682-684 (1991).

50) G. E. Youngblood, D. J. Senor and R. H. Jones, J. Nucl. Mater., 307-311, 1112-1119 (2002).

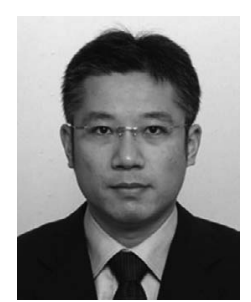

Katsumi Yoshida is an assistant professor at Tokyo Institute of Technology (Tokyo Tech.). He received Doctor of Engineering degree from Tokyo Tech. in 2001. He was a research fellow of the Japan Society for the Promotion of Science (JSPS) from 2000 to 2001. He worked at Chiba Institute of Technology as a research associate from 2001 to 2004, and he worked at Advanced Manufacturing Research Institute in AIST as a researcher from 2004 to 2007. He moved to Research Laboratory for Nuclear Reactors in Tokyo Tech. in 2007. His current research interests are development of high performance ceramics matrix composites and porous ceramics based on microstructure control. 